\title{
The Use of Platelet Rich Plasma, Bone Morphogenetic Protein-2 and Different Scaffolds in Oral and Maxillofacial Surgery - Literature Review in Comparison with Own Clinical Experience
}

\author{
Karl-Heinz Schuckert ${ }^{1}$, Stefan Jopp ${ }^{1}$, Magdalena Osadnik ${ }^{1}$ \\ ${ }^{1}$ Institute Indente - Institute of Innovative Oral Surgery and Medicine, Centre for Tissue Engineering, Hannover, Germany.
}

\author{
Corresponding Author: \\ Karl-Heinz Schuckert \\ Institute Indente - Institute of Innovative Oral Surgery and Medicine \\ Centre for Tissue Engineering, Hannover \\ Germany \\ Phone: +495118506232 \\ Fax: +49 511281757 \\ E-mail: k-h.schuckert@indente.de
}

\begin{abstract}
Objectives: The purpose of this article was to review and critically assess the use of platelet rich plasma, recombinant human bone morphogenetic protein-2 and different scaffolds (i.e. tricalciumphosphate, polycaprolactone, demineralized bone matrix and anorganic bovine bone mineral) in oral and maxillofacial surgery comparing the relevant literature and own clinical experience.

Material and Methods: A literature review was conducted using MEDLINE, MEDPILOT and COCHRANE DATABASE OF SYSTEMATIC REVIEWS. It concentrated on manuscripts and overviews published in the last five years (2006 - 2010). The key terms employed were platelet rich plasma, bone morphogenetic proteins and their combinations with the above mentioned scaffolds. The results of clinical studies and animal trials were especially emphasized. The statements from the literature were compared with authors' own clinical data.

Results: New publications and overviews demonstrate the advantages of platelet rich plasma in bone regeneration. The results from the literature review were discussed and compared with the publications detailing authors' own experiences.

Conclusions: A favourable outcome concerning newly grown bone was achieved combining platelet rich plasma in addition to optimal matrices with or without recombinant human bone morphogenetic protein-2, depending on the clinical case. As a consequence, the paradigm shift from transplantation of autogenous bone to bone tissue engineering appears promising.
\end{abstract}

Keywords: platelet-rich plasma; growth factors; bone morphogenetic protein 2; tissue engineering; bone regeneration; bone replacement materials.

\footnotetext{
Accepted for publication: 18 January 2011

To cite this article:

Schuckert KH, Jopp S, Osadnik M. The Use of Platelet Rich Plasma, Bone Morphogenetic Protein-2 and Different Scaffolds in Oral and Maxillofacial Surgery - Literature Review in Comparison with Own Clinical Experience.

J Oral Maxillofac Res 2011 (Jan-Mar);2(1):e2

URL: http://www.ejomr.org/JOMR/archives/2011/1/e2/v2n1e2ht.pdf

doi: 10.5037/jomr.2011.2102
} 


\section{INTRODUCTION}

Traditionally, the augmentation of bony defects in humans is carried out using allografts, xenografts, autogenous bone, and synthetic biomaterials. The transplantation of autogenous bone is regarded as the "gold standard". Globally, there are more than 2 million autogenous bone transplantations in humans each year in all parts of bone surgery $[1,2]$. Because of the osteoinductive and osteoconductive character [ $[\underline{3}]$ of autogenous bone, there are a number of good results obtained from transplantation $[4,5]$. However, there are disadvantages [6-9], namely:

1. In most cases, two surgical procedures are necessary: one for bone harvesting (e.g., from the iliac crest) and the other for implantation. This can cause suffering in some patients due to complications associated with the donor site (e.g. wound infection, chronic pain, nerve injuries, functional complications, bone fractures);

2. The risks in bone transplantation in the recipient site include wound infection, necrosis, and resorption, representing up to $30 \%$ of the transplanted material $[\underline{1}, \underline{2}]$.

Therefore the use of growth factors such as recombinant human bone morphogenetic protein-2 (rhBMP-2) and platelet rich plasma (PRP) has broken new ground in bone tissue engineering.

The purpose of this article was to review and critically assess the use of platelet rich plasma and recombinant human bone morphogenetic protein- 2 combined with different scaffolds in oral and maxillofacial surgery comparing the relevant literature and own clinical experience.

\section{MATERIAL AND METHODS}

A literature review was conducted using MEDLINE, MEDPILOT and COCHRANE DATABASE OF SYSTEMATIC REVIEWS. It concentrated on manuscripts and overviews published in the last five years (2006-2010). The key terms employed were platelet rich plasma (PRP), bone morphogenetic proteins (BMPs) and scaffolds used in combination. The results of clinical studies and animal trials were especially emphasised. We compared the statements from the literature with our own publications.

\section{Platelet rich plasma (PRP)}

The use of PRP therapy was introduced in the late 1990s. PRP offers an easy and cost-effective way to obtain high concentrations of growths factors for tissue healing and regeneration. It is a volume of plasma fraction of autologous blood having platelet concentrations above baseline (concentration in blood) obtained by two different steps of centrifugation. The concentration of PRP as well as the total amount that is inserted in the defect play an important role in the efficiency. In the published literature, there seems to be controversial discussion regarding the use of PRP and whether or not it favours bone regeneration $[10,11]$. Publications concerning animal trials and clinical studies in humans are not comparable to each other due to different methods. Hence different statements are presented as results regarding the effect of PRP on bone development.

However, all authors agree on the fact that platelets are the main regulators of the inflammatory phase and play an essential role in the proliferation and differentiation phase [12]. Disruption of the vascular structure as a result of injury leads to the formation of fibrin and platelet aggregation. A stable blood clot is then formed by coagulation of the blood. Subsequently, several growth factors are released into the injured tissue from the platelets and other cells that induce and support healing and tissue formation. To improve these effects surgeons developed higher concentration of platelets compared to baseline.

Amongst others, transforming growth factor (TGF- $\beta$ ), epidermal growth factor (EGF), insulin-like growth factor-1 (IGF-1) and platelet-derived growth factor (PDGF) are very important in bone regeneration $[13,14]$. For example, TGF- $\beta$ enhances the proliferative activity of fibroblasts, stimulates biosynthesis of type I collagen and fibronectin, induces deposition of bone matrix and inhibits osteoclast formation and bone resorption. EGF induces cellular proliferation and differentiation of epithelial cells. IGF-1 stimulates protein synthesis and enhances bone formation by proliferation and differentiation of osteoblasts. PDGF supports angiogenesis and enhances collagen synthesis and proliferation of bone cells $[\underline{13}, \underline{14}]$.

In addition, vascular endothelial growth factor (VEGF), basic fibroblast growth factor (bFGF), and plateletderived endothelial cell growth factor (PDECGF) play an essential role in angiogenesis, which is most important for nutrition of cells [15-17].

Most publications and overviews demonstrate the advantages of PRP in bone regeneration [18-20]. In 1998, Marx et al. proposed the use of PRP to enhance the initial phase of the bone wound healing [21]. A wound healing process is composed of three major phases:

1. The acute inflammatory phase which includes platelet aggregation and activation and the migration of granulocytes and macrophages; 
2. The mesenchymal cell proliferation and differentiation phase;

3. The phase of regeneration of the missing tissue by tissue-specific cells.

Marx et al. stated that monoclonal antibody assessment of cancellous cellular marrow grafts demonstrate cells that were capable of responding to the growth factors by bearing cell membrane receptors [21]. The additional amounts of these growth factors obtained by adding PRP to grafts evidenced a radiographic maturation rate which is 1.62 to 2.16 times higher than that of grafts without PRP. As assessed by histomorphometry, he also proved a greater bone density in grafts in which PRP was added $(74.0 \% \pm 11 \%)$ than in grafts in which PRP was not added $(55.1 \% \pm 8 \% ; \mathrm{P}=0.005)[21]$.

Current publications which support the positive effect of PRP to bone regeneration concentrate on the following facts and influence concerning PRP:

1. Importance of controlled release systems of growth and differentiation factors using biomaterials in combination with PRP [22];

2. Enhancement of osteogenesis and angiogenesis $[\underline{23}, 24]$;

3. Inhibition of osteoclast activation [25];

4. The enhancement of bone density adding PRP to a suboptimal doses of rhBMP-2 [26];

5. The activation of PRP using calcium chloride or/and thromboplastin solution [27];

6. A significant increase of early bone marrow stromal cells (BMSCs) proliferation and differentiation using the combination of rhBMP-2 and bFGB (one of the signaling molecules of PRP) [28];

7. Positive effect of PRP in bone regeneration in animal trials and clinical studies in humans [29-33];

8. Relevance of PDGF and transforming growth factors (TGF-al and TGF32) for bone regeneration [34]. The publications which point out negative results over the last years can be summarized in four groups:

1. The use of PRP in combination with anorganic bovine bone mineral (ABBM): several authors did not find any advantage in using PRP in addition to ABBM in bone development [35-37]. Fan et al. [38], Graziano et al. [39], Mata et al. [40], Kim et al. [41], Le Guehennec et al. [42] highlighted that osteoblasts have difficulties in adhering to smooth surfaces, but ABBM has a smooth surface $[43,44]$. Due to this, most attempts of creating new bone using ABBM may not be able to provide close contact between bone and the bovine material under reproducible conditions.

2. The second group combined PRP with autogenous bone, but could not improve the results by adding PRP to the autogenous bone.

Schaaf et al. used PRP for sinus lift augmentation with $11-12$ fold concentration to baseline [느]. From the other authors, we learned, that high concentrations of PRP produce negative effects such as suppression of proliferation of osteoblasts $[46,47]$. Three and a half fold to 8 fold concentrations of platelets in PRP compared to baseline seem to have the best effect.

Luaces-Rey et al. used only $10 \mathrm{ml}$ of venous blood to obtain PRP for alveolar cleft reconstruction [48]. This quantity seems to be insufficient. Our own experiences revealed that $10 \mathrm{ml}$ of venous blood lead to approximately $0.3 \mathrm{ml}$ of PRP after two steps of centrifugation. The total amount of PRP which is needed to be combined with suitable scaffolds depends on scaffold structure, porosity and surface.

Soaking $1 \mathrm{~cm}^{3}$ of TCP (Vitoss Micro-Morsels ${ }^{\circledR}$, Orthovita, PA, US) needs approximately $0.3 \mathrm{ml}$ of PRP.

The same volume of polycaprolactone (PCL) (OsteoMesh ${ }^{\circledR}$, Osteopore, Singapore) is able to absorb approximately $0.7 \mathrm{ml}$ of PRP. The needed quantity of augmentation material and PRP depends on the volume that has to be augmented $[\underline{49}, \underline{50}]$.

Nagata et al. [47] and Mariano et al. [51] worked on a rat calvarium model using critical sized defects (CRD) of $5 \mathrm{~mm}$ in diameter. The rat calvarium model however is established as $8-9 \mathrm{~mm}$ in literature $[\underline{47}, \underline{51}$.

The critical size defect model (CSD) is often used to study augmentation materials. It has been defined as the smallest in situ bone defect that could not heal spontaneously by bone formation during the lifespan of the animal. The CSD created on the bony vault of the cranium (calvaria) represents a severe test for bone graft substitutes. Compared with long bones, the skull is biologically rather inert due to a poor blood supply and a relative deficiency of bone marrow. CSDs in the calvaria have been established for different animal species [52-55].

In addition, investigators should remove the periosteum instead of preserving it during the bone formation in the bone graft model [56]. The remove of periosteum is an important part of a critical size defect model in animals, different to clinical applications in humans where the periosteum has to be preserved.

Other authors increased the bone level by combining autogenous bone and PRP $[\underline{18}, \underline{57}]$. Nagata et al. highlighted that there might be an optimal proportion between autogenous bone and PRP to influence bone healing in CSDs in rat calvaria [58].

3. The third group, Gürbüzer et al. [59], Forriol et al. [60], Pradeep et al. [61], tried to create new bone using PRP without any scaffold. Without structure providing matrices the development of newly grown bone seems to be an unobtainable target.

4. The fourth group representing Piemontese et al. [62], Trombelli and Farina [63], Harnack et al. [65], Powell et al. [64] reported on periodontal bone 
regeneration using the established muco-periosteal flap technique. In this surgical procedure the papilla is cut and a muco-periosteal flap is prepared from the alveolar bone. The reunification of the buckle and oral parts of the papilla results in a major difficulty because of the contained situation. Due to this, the risk of wound infection and loss of attachment is high. This might have caused the poor results. In addition, Harnack et al. [64] provided no information on activating the PRP but he reported on re-entry surgery after 6 months without implementing the background. We used calcium chloride $(100 \mathrm{mg} / \mathrm{ml})$ to activate the PRP [ $\underline{50}]$.

Modern bone regeneration in periodontology using PRP or/and BMPs requires a totally different surgical procedure. We have presented the bridge flap technique as a new approach to avoid wound healing disturbances and to increase the clinical outcome [66]. The important difference to the well-known flap technique is the preservation of the papillae. Thus, the invasion of bacteria in this critical region can be avoided.

\section{Models of bone tissue engineering}

Bone tissue engineering can be described in three different models:

1. CSD-model in cranial bone;

2. CSD-model in long bone;

3. Vertical bone development (onlay technique).

1. A great number of publications using PRP in combination with different scaffolds or in combination with autogenous bone could be found reporting on critical sized calvarial bone defects in rats and other animals. They all proved better results in the combination with PRP than without PRP $[\underline{67}, \underline{68}]$.

A totally different treatment is required in the regeneration of human cranial bone defects. Spector pointed out the advantage of regenerating tissues in vivo [56]. In this context, he stressed the importance of periosteum for nutrition of the augmentation area. Bone surgeons try to preserve the periosteum while treating humans with bony defects. Figure 1 explains bone regeneration in critical sized defects of the cranial bone.

2. Figure 2 shows the same situation in long bone defects. In both situations the periosteum is visible surrounding the augmentation material or at least is visible from both sides of the augmentation material. In animal trials the periosteum has to be removed before augmentation. As in the above-mentioned CSD-model concerning cranial defects several authors proved benefit of adding PRP to augmentation material in regenerating CSD in long bones in animal trials $[57,69,70]$.

3. A totally different issue appears in the model for bone tissue engineering in the vertical dimension using onlay technique (Figure 3). In this case, the periosteum

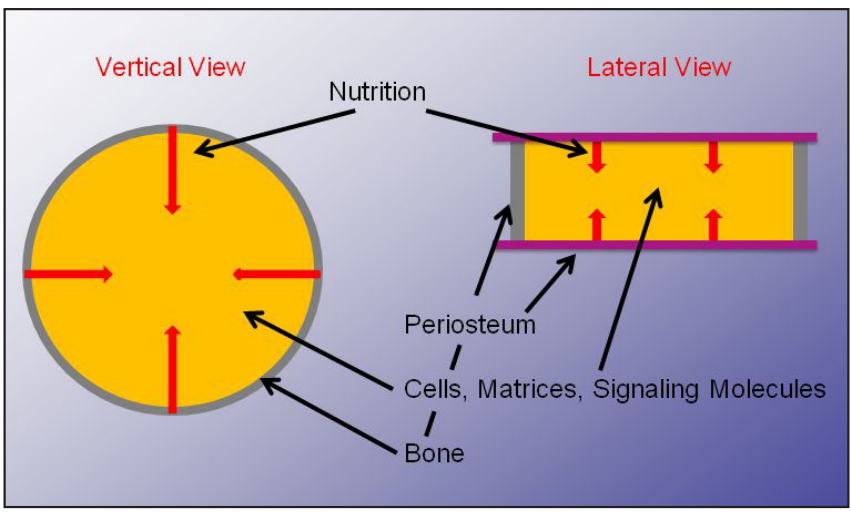

Figure 1. Model of bone regeneration in critical sized defects of cranial bone in humans (vertical and lateral view), augmentation material containing cells matrices and signaling molecules, surrounding bone and periosteum, nutrition is predominantly carried out by the periosteum.

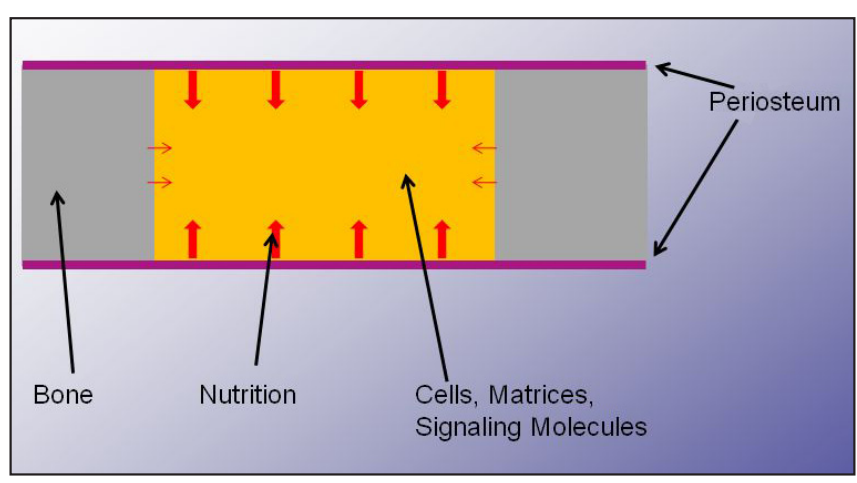

Figure 2. Model of bone regeneration in critical sized defects of long bone defects in humans, augmentation material containing cells matrices and signaling molecules, surrounding bone and periosteum, nutrition is predominantly carried out by the periosteum.

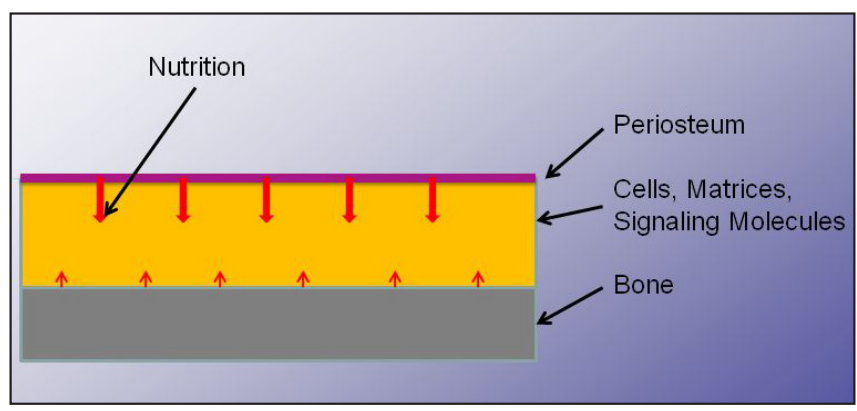

Figure 3. Model of vertical bone tissue engineering in humans, augmentation material containing cells matrices and signaling molecules, bone and periosteum only at one side, nutrition is predominantly carried out by the periosteum.

is only visible on top of the augmentation material. Due to this, nutrition is predominantly initiated from one side which means that a greater number of cells or a greater variety of cells is necessary. In addition, it also signifies that a greater number or a greater variety of signalling molecules has to be inserted in the augmentation material to recreate new bone in the required space.

No publication was found representing vertical bone development using PRP and scaffolds without adding 
signalling molecules in animal trials or clinical use in humans. Literature research presented a huge number of publications concerning autogenous bone grafting in onlay technique [71-79].

In cases of alveolar ridge atrophy, in addition to bone transplantation, a special technique (called distraction osteogenesis) is employed. In this treatment, the alveolar ridge is split horizontally into two parts. Osteodistraction devices are fixed on both sides. The gap between both parts of the bone is filled with autogenous bone or this gap regenerates through osteogenesis by distracting both sides at a rate of 0.5 to $1 \mathrm{~mm}$ a day. This treatment is carried out for one to two weeks followed by a period of consolidation of two to three months. Due to this, patients have to wear this osteodistractor for several months, which means a severe impairment of their quality of life [ 80-85].

In those cases, where the fixation of screws for the stabilization of the transplantation material is impossible and no osteodistraction devices can be fixed, traditional surgical treatments are unable to help. Here, only bone regeneration by means of tissue engineering techniques seems to provide a solution for the patients.

Without bone grafting, concentrated growth factors must be added to scaffolds in order to obtain vertical development of a newly grown bone. This was proved by Polimeni et al. using dental implants covered with growth factors [86]. Schuckert et al. reported on vertical augmentation of maxillary bone in a single case using TCP, PRP and rhBMP-2 [마]. Between 6 and $8 \mathrm{~mm}$ of vertical and horizontal bone development was achieved.

\section{Bone tissue engineering using bone morphogenetic proteins (BMPs)}

A variety of different techniques have been developed in bone tissue engineering during the last 20 years. In 1965, Urist wrote about bone growth by induction [87] Meanwhile, several thousand international manuscripts have been published on this innovative treatment.

Zheng et al. reported at an early stage that rhBMP-2 induces endochondral ossification [88]. It supports:

1. Proliferation and differentiation of mesenchymal cells into chondroblasts and osteoblasts;

2. Production and maturation of cartilage and bone matrix;

3. Differentiation of circulating osteoclast precursor cells into osteoclasts.

Furthermore, Raida et al. [89] proved that rhBMP-2 promotes vascularisation.

In the field of oral and maxillofacial surgery, different authors have reported about newly regenerated bone in animal models using growth factors [90-99]. They have published the first clinical studies about bone regeneration in humans with rhBMP-2 in dental application. Jung et al. [100] and Warnke et al. [101] combined xenogenic anorganic bovine bone mineral with BMPs (rhBMP-2 and rhBMP-7 with OP-1 [Stryker, Kalamazoo, MI, USA]) for jawbone reconstruction in single cases. Both BMPs are prefabricated with a bovine collagen sponge as carrier material. OP-1 contains a mixture of rhBMP-7 powder and granulated absorbable collagen sponge. INFUSE ${ }^{\circledR} /$ InductOs $^{\circledR}$ (Medtronic Sofamor Danek, MN, USA) is provided as rhBMP-2 powder and a separate collagen sponge. Absorbable collagen sponge is bovine (xenogenic) material that causes immunological reactions in $18 \%$ of patients [102]. Moreover, absorbable collagen sponge is not able to provide suitable structural support for the agglomeration of osteoblasts to reconstruct larger bony defects [103]. Only INFUSE ${ }^{\circledR} /$ InductOs $^{\circledR}$ enables a complete splitting of both parts.

We have demonstrated the advantages of combining rhBMP-2 with other carrier materials such as demineralised bone matrix (DBM - Grafton ${ }^{\circledR}$, Osteotech, NJ, US) which is allogenic material and scaffolds instead of absorbable collagen sponge $[\underline{103}, \underline{104}]$.

\section{Negative aspects of bone morphogenetic proteins (BMPs)}

Although most of the authors present favourable results using BMPs the disadvantages have to be mentioned. One of them is high cost. Furthermore, BMPs induce the development of osteoblasts and osteoclasts, which means that a contrary development to the main target is also initiated. This negative effect can be partly counteracted by combining the BMPs with PRP.

Cenni et al. proved the inhibition of osteoclast activation using PRP [25]. He stated that the effect of PRP on osteoclasts has been only scarcely investigated even though these cells are crucial for bone remodelling. The aim of his research was the evaluation of the effects of thrombin-activated platelets on osteoclastogenesis from human blood precursors. PRP even at a low concentration reduces the osteoclast-mediated bone collagen degradation.

\section{Demineralized bone matrix (DBM)}

Demineralized bone matrix (DBM), a form of allograft, possesses the properties of osteoinductivity [105107] and osteoconductivity [108]. A large body of data obtained from extensive preclinical studies has supported the effectiveness of DBM or demineralized freeze-dried bone allograft (DFDBA) in human clinical settings. But it is important to mention that DBM products differ concerning their biological properties 
due to the host environment, the methods of allograft preparation, particle size and shape and donor selection criteria. DBM functions best in a healthy tissue bed but can be expected to have little impact in an anoxic or avascular tissue bed [109]. As an allogenic material, DBM opens the potential for disease transmission.

\section{Clinical relevance of demineralized bone matrix (DBM)}

In in vitro tests DBM enhanced the osteogenetic differentiation [110]. DBM proved good results as a graft extender for spinal fusion [111] and as augmentation material used to treat uncomplicated bone defects [112]. Compared to autologous bone, DBM performed equally well in posterolateral lumbar spine fusion [113] and in anterior cervical fusion [114]. An allogenous DBM represents a potential scaffold for bone tissue engineering [115]. Pieske et al. demonstrated in their clinical study, using autologous bone graft versus DBM in the internal fixation of ununited long bones that the application of DBM compared to iliac crest autologous bone grafting led to a better outcome and simultaneously to a decreased quantity of adverse effects [116]. The combination of DBM and PRP increases the proliferation of human bone marrow stromal cells (hBMSC), as well as the osteoblastic differentiation and bone formation compared with PRP alone [117] or DBM alone [118].

The augmentation of bone defects in the oral cavity using DBM exclusively was reported by Kuvat et al. [119] and Sohn et al. [120]. Both authors presented an increased bone volume in combination with Le Fort I osteotomy and maxillary sinus augmentation. However, no bone development could be achieved in periodontal surgery using DBM alone $[\underline{121}, \underline{122}]$.

\section{Combination of demineralized bone matrix (DBM) and bone morphogenetic proteins (BMPs)}

While Lin et al. [123] and Zhao et al. [124] reported on a limited BMP-2 binding ability of DBM, which could be increased using heparin or cyclic thioimidate, Tsiridis et al. proved an optimized osteoinduction using DBM combined with rhBMP-7 compared with DBM alone [125]. These results are supported by Clokie and Sándor in their review of 10 clinical cases with major mandibular defects [126]. They implanted DBM soaked with rhBMP-7 and were successful in restoring the defects. Due to this background and the negative aspects of absorbable collagen sponge, we substituted DBM by absorbable collagen sponge. In addition, DBM provided a scaffold function which absorbable collagen sponge did not. In 2006, we presented the first case with successful bone regeneration without existing bony walls in periodontal surgery using DBM in combination with rhBMP-2 and PRP [6].

Polycaprolactone (PCL) in combination with bone morphogenetic proteins (BMPs) and platelet rich plasma (PRP)

Hutmacher [127] and Zein [128] have presented a suitable three-dimensional PCL scaffold that can be used for augmentation purposes. This scaffold has been tested as a delivery system for PRP [129] and for rhBMP-2 $[130,131]$. The reconstruction of critical sized defects in the oral cavity of humans was successfully achieved using PCL soaked with PRP and rhBMP-2. In this connection, the long time of biodegradation of PCL (approximately 12 months) proved as disadvantage in our treatment [누].

Tricalcium phosphate (TCP) in combination with bone morphogenetic proteins (BMPs) and platelet rich plasma (PRP)

Tricalcium phosphate (TCP) is an established anorganic augmentation material in bone surgery throughout the world $[\underline{1}, 2]$. The osteoinductive potential of hydroxyapatite and injectable biomaterials for regenerating bone was demonstrated by Tsiridis et al. [132] and Kretlow et al. [133]. Basically, the use of PRP in the bone regeneration has improved the results in the bone surgery. Ripamonti et al. [134] and Heliotis et al. [135] described in their overviews the potential of growth factors and their relevance for bone induction in the clinical use. Wikesjö et al. [136-139] and Leknes et al. $[140,141]$ highlighted the new method of alveolar ridge augmentation using implants coated with bone morphogenetic proteins.

The combination of TCP, rhBMP-2 and PRP enables us not only to regenerate bone in defects but also to recreate bone in a vertical direction. Compared with PCL, combinations of PRP, rhBMP-2 and TCP can be shaped easily during the surgical treatment. TCP is available as blocks and strips, which are flexible, and in form of granules. PCL, however, is not provided as small shaped particles. In 2010, we published a case where we regenerated a complete alveolar ridge in the maxilla of a woman, who suffered from alveolar ridge atrophy due to a long time of wearing a denture [ $\underline{50}]$. A TCP block of $100 \times 25 \times 5 \mathrm{~mm}$ (Vitoss ${ }^{\circledR}$, Stryker, Malvern PA, US) was cut into smaller pieces and was soaked with activated PRP and rhBMP-2 $(12 \mathrm{mg} ; 1.5 \mathrm{mg} / \mathrm{ml})$ (INFUSE ${ }^{\circledR} /$ InductOs $^{\circledR}$, Medtronic Sofamor Danek, MN, USA). These blocks were implanted endoscopically assisted between the residual bone and the periosteum. They were attached by tightening the soft tissue 
including the periosteum. Four months after augmentation, newly grown bone could be proved radiographically and by taking bone samples in combination with the placement of six dental implants. Another four months later, the implants were osseointegrated and could be loaded.

To our knowledge this is the first case which could be treated successfully this way.

\section{CONCLUSIONS}

It is not possible to compare the published clinical studies and animal trials concerning PRP and/or BMPs against each other due to the varying methodologies applied. However, single results especially in their summation could be evaluated.

From our point of view, comparable multicenter clinical studies should be carried out in the future.

Our critical assessment of the literature seems to emphasise, that bone tissue engineering techniques using suitable scaffolds combined with PRP and rhBMP-2 offer new options in reconstructive bone surgery. Current publications point out advantages in the bone regeneration using PRP combined with suitable scaffolds in comparison to the use without PRP. This was proved in critical sized defects in animals as well as in the treatment of humans and depends on signalling molecules released through the platelets. The induction of angiogenesis plays an important role concerning bone regeneration.

In cases of vertical bone development, the transplantation of autogenous bone is regarded as the "gold standard" till today. Due to the background of inevitable risks on the harvesting as well as on the recipient site, the transplantation of autogenous bone must be considered critically. Especially in the surgical treatment of multimorbid old patients the minimisation of risks has to be taken into account. Here, the new bone tissue engineering techniques offer alternatives. Cases, in which the residual bone does not allow to fix screws, can only be treated by means of tissue engineering techniques.

Adding PRP to BMPs suppresses the osteoclast induction of BMPs which counteracts to the development of newly grown bone. Thus, the amount of added signalling molecules can be reduced. Therefore, the clinical results can be improved and the costs decrease.

In the field of oral and maxillofacial surgery, where surgeons deal with well vascularised soft tissue, conditions for bone regeneration appear better than in trauma surgery. In addition, most interventions are performed as elective surgery. Thus the approach can be prepared precisely and performed with greater care. Hence, surgeons are able to preserve the covering periosteum which is necessary for nutrition and therefore for bone regeneration.

As a consequence, the paradigm shift from transplantation of autogenous bone to bone tissue engineering appears promising.

\section{ACKNOWLEDGMENTS AND DISCLOSURE STATEMENTS}

The authors wish to thank Ms. Conny Helbling for her linguistic review as a native speaker certified as English teacher.

\section{REFERENCES}

1. Betz RR. Limitations of autograft and allograft: new synthetic solutions. Orthopedics. 2002 May;25(5 Suppl):s561-70. Review. [Medline: 12038843]

2. Horch HH, Pautke C. [Regeneration instead of reparation: a critical review of the autogenous bone transplant as "golden standard" of reconstructive oral surgery]. Mund Kiefer Gesichtschir. 2006 Jul;10(4):213-20. Review. German. [Medline: 16802135] [doi: 10.1007/s10006-006-0004-x]

3. Springer IN, Nocini PF, Schlegel KA, De Santis D, Park J, Warnke PH, Terheyden H, Zimmermann R, Chiarini L, Gardner K, Ferrari F, Wiltfang J. Two techniques for the preparation of cell-scaffold constructs suitable for sinus augmentation: steps into clinical application. Tissue Eng. 2006 Sep;12(9):2649-56. [Medline: 16995798] [doi: $10.1089 /$ ten.2006.12.2649]

4. van Gemert JT, van Es RJ, Van Cann EM, Koole R. Nonvascularized bone grafts for segmental reconstruction of the mandible--a reappraisal. J Oral Maxillofac Surg. 2009 Jul;67(7):1446-52. [Medline: 19531416] [doi: 10.1016/j.joms.2008.12.052]

5. Carlini JL, Biron C, Gomes KU, Da Silva RM. Surgical repositioning of the premaxilla with bone graft in 50 bilateral cleft lip and palate patients. J Oral Maxillofac Surg. 2009 Apr;67(4):760-6. [Medline: 19304031] [doi: 10.1016/j.joms.2008.07.013] 
6. Le BT, Woo I. Alveolar cleft repair in adults using guided bone regeneration with mineralized allograft for dental implant site development: a report of 2 cases. J Oral Maxillofac Surg. 2009 Aug;67(8):1716-22. [Medline: 19615587] [doi: 10.1016/j.joms.2009.04.012]

7. Esposito M, Grusovin MG, Felice P, Karatzopoulos G, Worthington HV, Coulthard P. The efficacy of horizontal and vertical bone augmentation procedures for dental implants - a Cochrane systematic review. Eur J Oral Implantol. 2009 Autumn;2(3):167-84. Review. [Medline: 20467628]

8. Esposito M, Grusovin MG, Kwan S, Worthington HV, Coulthard P. Interventions for replacing missing teeth: bone augmentation techniques for dental implant treatment. Cochrane Database Syst Rev. 2008 Jul 16;(3):CD003607. Review. Update in: Cochrane Database Syst Rev. 2009;(4):CD003607. [Medline: 18646092]

9. Tezulas E, Dilek OC. Decontamination of autogenous bone grafts collected from dental implant sites via osteotomy: a review. Oral Surg Oral Med Oral Pathol Oral Radiol Endod. 2008 Nov;106(5):679-84. Epub 2008 Aug 28. Review. [Medline: 18755618] [doi: 10.1016/j.tripleo.2008.05.041]

10. Plachokova AS, Nikolidakis D, Mulder J, Jansen JA, Creugers NH. Effect of platelet-rich plasma on bone regeneration in dentistry: a systematic review. Clin Oral Implants Res. 2008 Jun;19(6):539-45. Epub 2008 Apr 16. Review. [Medline: 18422984] [doi: 10.1111/j.1600-0501.2008.01525.x]

11. Nikolidakis D, Jansen JA. The biology of platelet-rich plasma and its application in oral surgery: literature review. Tissue Eng Part B Rev. 2008 Sep;14(3):249-58. Review. [Medline: 18601587] [doi: 10.1089/ten.teb.2008.0062]

12. Intini G. The use of platelet-rich plasma in bone reconstruction therapy. Biomaterials. 2009 Oct;30(28):4956-66. Epub 2009 Jul 1. Review. [Medline: 19573909] [doi: 10.1016/j.biomaterials.2009.05.055]

13. Harrison P, Cramer EM. Platelet alpha-granules. Blood Rev. 1993 Mar;7(1):52-62. Review. [Medline: 8467233] [doi: $10.1016 / 0268-960 X(93) 90024-X]$

14. Marx RE. Platelet-rich plasma (PRP): what is PRP and what is not PRP? Implant Dent. 2001;10(4):225-8. [Medline: 11813662]

15. Abraham JA, Mergia A, Whang JL, Tumolo A, Friedman J, Hjerrild KA, Gospodarowicz D, Fiddes JC. Nucleotide sequence of a bovine clone encoding the angiogenic protein, basic fibroblast growth factor. Science. 1986 Aug 1;233(4763):545-8. [Medline: 2425435] [doi: 10.1126/science.2425435]

16. Sánchez AR, Sheridan PJ, Kupp LI. Is platelet-rich plasma the perfect enhancement factor? A current review. Int J Oral Maxillofac Implants. 2003 Jan-Feb;18(1):93-103. [Medline: 12608674]

17. Einhorn TA. The science of fracture healing. J Orthop Trauma. 2005 Nov-Dec;19(10 Suppl):S4-6. [Medline: 16479221] [doi: 10.1097/00005131-200511101-00002]

18. Tomoyasu A, Higashio K, Kanomata K, Goto M, Kodaira K, Serizawa H, Suda T, Nakamura A, Nojima J, Fukuda T, Katagiri T. Platelet-rich plasma stimulates osteoblastic differentiation in the presence of BMPs. Biochem Biophys Res Commun. 2007 Sep 14;361(1):62-7. Epub 2007 Jul 5. [Medline: 17632078] [doi: 10.1016/j.bbrc.2007.06.142]

19. Sampson S, Gerhardt M, Mandelbaum B. Platelet rich plasma injection grafts for musculoskeletal injuries: a review. Curr Rev Musculoskelet Med. 2008 Dec;1(3-4):165-74. [Medline: 19468902] [doi: 10.1007/s12178-008-9032-5] [FREE Full Text]

20. Alsousou J, Thompson M, Hulley P, Noble A, Willett K. The biology of platelet-rich plasma and its application in trauma and orthopaedic surgery: a review of the literature. J Bone Joint Surg Br. 2009 Aug;91(8):987-96. Review. [Medline: 19651823] [doi: 10.1302/0301-620X.91B8.22546]

21. Marx RE, Carlson ER, Eichstaedt RM, Schimmele SR, Strauss JE, Georgeff KR. Platelet-rich plasma: Growth factor enhancement for bone grafts. Oral Surg Oral Med Oral Pathol Oral Radiol Endod. 1998 Jun;85(6):638-46. [Medline: 9638695] [doi: 10.1016/S1079-2104(98)90029-4]

22. Bertoldi C, Pinti M, Zaffe D, Cossarizza A, Consolo U, Ceccherelli GB. Morphologic, histochemical, and functional analysis of platelet-rich plasma activity on skeletal cultured cells. Transfusion. 2009 Apr 22. [Epub ahead of print] [Medline: 19413738]

23. Hu ZM, Peel SA, Ho SK, Sándor GK, Clokie CM. Comparison of platelet-rich plasma, bovine BMP, and rhBMP-4 on bone matrix protein expression in vitro. Growth Factors. 2009 Oct;27(5):280-8. [Medline: 19637071] [doi: 10.1080/08977190903137819]

24. Yokota K, Ishida O, Sunagawa T, Suzuki O, Nakamae A, Ochi M. Platelet-rich plasma accelerated surgical angiogenesis in vascular-implanted necrotic bone: an experimental study in rabbits. Acta Orthop. 2008 Feb;79(1):106-10. [Medline: 18283581] [doi: 10.1080/17453670710014842]

25. Cenni E, Avnet S, Fotia C, Salerno M, Baldini N. Platelet-rich plasma impairs osteoclast generation from human precursors of peripheral blood. J Orthop Res. 2010 Jun;28(6):792-7. [Medline: 20058277]

26. Park EJ, Kim ES, Weber HP, Wright RF, Mooney DJ. Improved bone healing by angiogenic factor-enriched platelet-rich plasma and its synergistic enhancement by bone morphogenetic protein-2. Int J Oral Maxillofac Implants. 2008 SepOct;23(5):818-26. [Medline: 19014150] [FREE Full Text]

27. Lu HH, Vo JM, Chin HS, Lin J, Cozin M, Tsay R, Eisig S, Landesberg R. Controlled delivery of platelet-rich plasmaderived growth factors for bone formation. J Biomed Mater Res A. 2008 Sep 15;86(4):1128-36. [Medline: 18181109] [doi: $10.1002 / \mathrm{jbm} . \mathrm{a} .31740$ ] 
28. Wang L, Huang Y, Pan K, Jiang X, Liu C. Osteogenic responses to different concentrations/ratios of BMP2 and bFGF in bone formation. Ann Biomed Eng. 2010 Jan;38(1):77-87. Epub 2009 Nov 17. [Medline: 19921434] [doi: $10.1007 / \mathrm{s} 10439-009-9841-8$ ]

29. Choi BH, Im CJ, Huh JY, Suh JJ, Lee SH. Effect of platelet-rich plasma on bone regeneration in autogenous bone graft. Int J Oral Maxillofac Surg. 2004 Jan;33(1):56-9. [Medline: 14690660] [doi: 10.1054/ijom.2003.0466]

30. Marx RE. Platelet-rich plasma: evidence to support its use. J Oral Maxillofac Surg. 2004 Apr;62(4):489-96. Review. [Medline: $\underline{15085519}$ ] [doi: 10.1016/j.joms.2003.12.003]

31. Wiltfang J, Kloss FR, Kessler P, Nkenke E, Schultze-Mosgau S, Zimmermann R, Schlegel KA. Effects of platelet-rich plasma on bone healing in combination with autogenous bone and bone substitutes in criticalsize defects. An animal experiment. Clin Oral Implants Res. 2004 Apr;15(2):187-93. [Medline: 15008930] [doi: 10.1111/j.1600-0501.2004.00980.x]

32. Fennis JP, Stoelinga PJ, Jansen JA. Reconstruction of the mandible with an autogenous irradiated cortical scaffold, autogenous corticocancellous bone-graft and autogenous platelet-rich-plasma: an animal experiment. Int J Oral Maxillofac Surg. 2005 Mar;34(2):158-66. [Medline: 15695045] [doi: 10.1016/j.ijom.2004.06.004]

33. Okuda K, Tai H, Tanabe K, Suzuki H, Sato T, Kawase T, Saito Y, Wolff LF, Yoshiex H. Platelet-rich plasma combined with a porous hydroxyapatite graft for the treatment of intrabony periodontal defects in humans: a comparative controlled clinical study. J Periodontol. 2005 Jun;76(6):890-8. [Medline: 15948682] [doi: 10.1902/jop.2005.76.6.890]

34. Graham S, Leonidou A, Lester M, Heliotis M, Mantalaris A, Tsiridis E. Investigating the role of PDGF as a potential drug therapy in bone formation and fracture healing. Expert Opin Investig Drugs. 2009 Nov;18(11):1633-54. Review. [Medline: 19747084] [doi: 10.1517/13543780903241607]

35. Camargo PM, Lekovic V, Weinlaender M, Divnic-Resnik T, Pavlovic M, Kenney EB. A surgical reentry study on the influence of platelet-rich plasma in enhancing the regenerative effects of bovine porous bone mineral and guided tissue regeneration in the treatment of intrabony defects in humans. J Periodontol. 2009 Jun;80(6):915-23. [Medline: 19485821] [doi: 10.1902/jop.2009.080600]

36. Döri F, Kovács V, Arweiler NB, Huszár T, Gera I, Nikolidakis D, Sculean A. Effect of platelet-rich plasma on the healing of intrabony defects treated with an anorganic bovine bone mineral: a pilot study. J Periodontol. 2009 Oct;80(10):1599-605. [Medline: 19792848] [doi: 10.1902/jop.2009.090058]

37. Mooren RE, Dankers AC, Merkx MA, Bronkhorst EM, Jansen JA, Stoelinga PJ. The effect of platelet-rich plasma on early and late bone healing using a mixture of particulate autogenous cancellous bone and Bio-Oss: an experimental study in goats. Int J Oral Maxillofac Surg. 2010 Apr;39(4):371-8. Epub 2010 Feb 2. [Medline: 20129756] [doi: 10.1016/i.ijom.2009.12.019]

38. Fan Z, Jia S, Su JS. [Influence of surface roughness of titanium implant on core binding factor alpha 1 subunit of osteoblasts]. Zhonghua Kou Qiang Yi Xue Za Zhi. 2010 Aug;45(8):466-70. Chinese. [Medline: 21122362]

39. Graziano A, d'Aquino R, Cusella-De Angelis MG, Laino G, Piattelli A, Pacifici M, De Rosa A, Papaccio G. Concave pit-containing scaffold surfaces improve stem cell-derived osteoblast performance and lead to significant bone tissue formation. PLoS One. 2007 Jun 6;2(6):e496. [Medline: 17551577] [doi: 10.1371/journal.pone.0000496] [FREE Full Text]

40. Mata A, Kim EJ, Boehm CA, Fleischman AJ, Muschler GF, Roy S. A three-dimensional scaffold with precise microarchitecture and surface micro-textures. Biomaterials. 2009 Sep;30(27):4610-7. Epub 2009 Jun 12. [Medline: 19524292] [doi: 10.1016/i.biomaterials.2009.05.023]

41. Kim EJ, Boehm CA, Fleischman AJ, Muschler GF, Kostov YV, Roy S. Modulating human connective tissue progenitor cell behavior on cellulose acetate scaffolds by surface microtextures. J Biomed Mater Res A. 2009 Sep 15;90(4):1198-205. [Medline: $\underline{18680188}$ ] [doi: $10.1002 / \mathrm{jbm}$. a.32160]

42. Le Guehennec L, Lopez-Heredia MA, Enkel B, Weiss P, Amouriq Y, Layrolle P. Osteoblastic cell behaviour on different titanium implant surfaces. Acta Biomater. 2008 May;4(3):535-43. Epub 2007 Dec 10. [Medline: 18226985] [doi: 10.1016/j.actbio.2007.12.002]

43. Asti A, Visai L, Dorati R, Conti B, Saino E, Sbarra S, Gastaldi G, Benazzo F. Improved cell growth by Bio-Oss/PLA scaffolds for use as a bone substitute. Technol Health Care. 2008;16(6):401-13. [Medline: 19212036]

44. Herten M, Rothamel D, Schwarz F, Friesen K, Koegler G, Becker J. Surface- and nonsurface-dependent in vitro effects of bone substitutes on cell viability. Clin Oral Investig. 2009 Jun;13(2):149-55. Epub 2008 Aug 8. [Medline: 18688661] [doi: 10.1007/s00784-008-0214-8]

45. Schaaf H, Streckbein P, Lendeckel S, Heidinger KS, Rehmann P, Boedeker RH, Howaldt HP. Sinus lift augmentation using autogenous bone grafts and platelet-rich plasma: radiographic results. Oral Surg Oral Med Oral Pathol Oral Radiol Endod. 2008 Nov;106(5):673-8. Epub 2008 Jul 7. [Medline: 18602312] [doi: 10.1016/j.tripleo.2008.04.004]

46. Choi BH, Zhu SJ, Kim BY, Huh JY, Lee SH, Jung JH. Effect of platelet-rich plasma (PRP) concentration on the viability and proliferation of alveolar bone cells: an in vitro study. Int J Oral Maxillofac Surg. 2005 Jun;34(4):420-4. Epub 2005 Jan 27. [Medline: 16053853] [doi: 10.1016/j.ijom.2004.10.018]

47. Nagata MJ, Messora M, Pola N, Campos N, Vieira R, Esper LA, Sbrana M, Fucini S, Garcia V, Bosco A. Influence of the ratio of particulate autogenous bone graft/platelet-rich plasma on bone healing in critical-size defects: a histologic and histometric study in rat calvaria. J Orthop Res. 2010 Apr;28(4):468-73. [Medline: 19890994] 
48. Luaces-Rey R, Arenaz-Búa J, Lopez-Cedrún-Cembranos JL, Herrero-Patiño S, Sironvalle-Soliva S, Iglesias-Candal E, Pombo-Castro M. Is PRP useful in alveolar cleft reconstruction? Platelet-rich plasma in secondary alveoloplasty. Med Oral Patol Oral Cir Bucal. 2010 Jul 1;15(4):e619-23. [Medline: 20038881] [doi: 10.4317/medoral.15.e619] [FREE Full Text]

49. Schuckert KH, Jopp S, Teoh SH. Mandibular defect reconstruction using three-dimensional polycaprolactone scaffold in combination with platelet-rich plasma and recombinant human bone morphogenetic protein-2: de novo synthesis of bone in a single case. Tissue Eng Part A. 2009 Mar;15(3):493-9. [Medline: 18767969] [doi: 10.1089/ten.tea.2008.0033]

50. Schuckert KH, Jopp S, Osadnik M. Modern bone regeneration instead of bone transplantation: a combination of recombinant human bone morphogenetic protein-2 and platelet-rich plasma for the vertical augmentation of the maxillary bone-a single case report. Tissue Eng Part C Methods. 2010 Dec;16(6):1335-46. Epub 2010 Apr 26. [Medline: 20302447] [doi: 10.1089/ten.tec.2010.0020]

51. Mariano R, Messora M, de Morais A, Nagata M, Furlaneto F, Avelino C, Paula F, Ferreira S, Pinheiro M, de Sene JP. Bone healing in critical-size defects treated with platelet-rich plasma: a histologic and histometric study in the calvaria of diabetic rat. Oral Surg Oral Med Oral Pathol Oral Radiol Endod. 2010 Jan;109(1):72-8. Epub 2009 Nov 17. [Medline: 19926499] [doi: 10.1016/j.tripleo.2009.08.003]

52. Schmitz JP, Hollinger JO. The critical size defect as an experimental model for craniomandibulofacial nonunions. Clin Orthop Relat Res. 1986 Apr;(205):299-308. [Medline: 3084153]

53. Hollinger JO, Kleinschmidt JC. The critical size defect as an experimental model to test bone repair materials. J Craniofac Surg. 1990 Jan;1(1):60-8. [Medline: 1965154] [doi: 10.1097/00001665-199001000-00011]

54. Montjovent MO, Mathieu L, Schmoekel H, Mark S, Bourban PE, Zambelli PY, Laurent-Applegate LA, Pioletti DP. Repair of critical size defects in the rat cranium using ceramic-reinforced PLA scaffolds obtained by supercritical gas foaming. J Biomed Mater Res A. 2007 Oct;83(1):41-51. [Medline: 17377968] [doi: 10.1002/jbm.a.31208]

55. Patel ZS, Young S, Tabata Y, Jansen JA, Wong ME, Mikos AG. Dual delivery of an angiogenic and an osteogenic growth factor for bone regeneration in a critical size defect model. Bone. 2008 Nov;43(5):931-40. Epub 2008 Jul 14. [Medline: 18675385] [FREE Full Text]

56. Spector M. Biomaterials-based tissue engineering and regenerative medicine solutions to musculoskeletal problems. Swiss Med Wkly. 2007 Mar 2;137 Suppl 155:157S-165S. [Medline: 17874524]

57. Hakimi M, Jungbluth P, Sager M, Betsch M, Herten M, Becker J, Windolf J, Wild M. Combined use of platelet-rich plasma and autologous bone grafts in the treatment of long bone defects in mini-pigs. Injury. 2010 Jul;41(7):717-23. Epub 2010 Jan 25. [Medline: 20097341] [doi: 10.1016/j.injury.2009.12.005]

58. Nagata M, Messora M, Okamoto R, Campos N, Pola N, Esper L, Sbrana M, Fucini S, Garcia V, Bosco A. Influence of the proportion of particulate autogenous bone graft/platelet-rich plasma on bone healing in critical-size defects: an immunohistochemical analysis in rat calvaria. Bone. 2009 Aug;45(2):339-45. Epub 2009 May 3. [Medline: 19410024]

59. Gürbüzer B, Pikdöken L, Urhan M, Süer BT, Narin Y. Scintigraphic evaluation of early osteoblastic activity in extraction sockets treated with platelet-rich plasma. J Oral Maxillofac Surg. 2008 Dec;66(12):2454-60. [Medline: 19022123] [doi: 10.1016/j.joms.2008.03.006]

60. Forriol F, Longo UG, Concejo C, Ripalda P, Maffulli N, Denaro V. Platelet-rich plasma, rhOP-1 (rhBMP-7) and frozen rib allograft for the reconstruction of bony mandibular defects in sheep. A pilot experimental study. Injury. 2009 Dec;40 Suppl 3:S44-9. [Medline: 20082791] [doi: 10.1016/S0020-1383(09)70011-7]

61. Pradeep AR, Pai S, Garg G, Devi P, Shetty SK. A randomized clinical trial of autologous platelet-rich plasma in the treatment of mandibular degree II furcation defects. J Clin Periodontol. 2009 Jul;36(7):581-8. [Medline: 19538331] [doi: 10.1111/j.1600-051X.2009.01428.x]

62. Piemontese M, Aspriello SD, Rubini C, Ferrante L, Procaccini M. Treatment of periodontal intrabony defects with demineralized freeze-dried bone allograft in combination with platelet-rich plasma: a comparative clinical trial. J Periodontol. 2008 May;79(5):802-10. [Medline: 18454658] [doi: 10.1902/jop.2008.070436]

63. Trombelli L, Farina R. Clinical outcomes with bioactive agents alone or in combination with grafting or guided tissue regeneration. J Clin Periodontol. 2008 Sep;35(8 Suppl):117-35. Review. [Medline: 18724846] [doi: 10.1111/j.1600-051X.2008.01265.x]

64. Harnack L, Boedeker RH, Kurtulus I, Boehm S, Gonzales J, Meyle J. Use of platelet-rich plasma in periodontal surgery-a prospective randomised double blind clinical trial. Clin Oral Investig. 2009 Jun;13(2):179-87. Epub 2008 Sep 3. [Medline: 18766387] [doi: 10.1007/s00784-008-0223-7]

65. Powell CA, Bannister SR, Mackey SA, Maller SC, McDonnell HT, Deas DE. Periodontal wound healing with and without platelet-rich plasma: histologic observations and assessment of flap tensile strength. J Periodontol. 2009 Jun;80(6):985-92. [Medline: 19485830] [doi: 10.1902/jop.2009.080626]

66. Schuckert KH, Jopp S, Müller U. Use of rhBMP-2 in periodontal surgery - micro surgical reconstruction and flap. Deutsche Zahnärztliche Zeitschrift. 2006 Apr;61(5):259-61.

67. Findikcioglu K, Findikcioglu F, Yavuzer R, Elmas C, Atabay K. Effect of platelet-rich plasma and fibrin glue on healing of critical-size calvarial bone defects. J Craniofac Surg. 2009 Jan;20(1):34-40. [Medline: 19164985] [doi: 10.1097/SCS.0b013e318190ddb9] 
68. Kim ES, Kim JJ, Park EJ. Angiogenic factor-enriched platelet-rich plasma enhances in vivo bone formation around alloplastic graft material. J Adv Prosthodont. 2010 Mar;2(1):7-13. Epub 2010 Mar 31. [Medline: 21165181] [doi: 10.4047/jap.2010.2.1.7] [FREE Full Text]

69. Dallari D, Fini M, Stagni C, Torricelli P, Nicoli Aldini N, Giavaresi G, Cenni E, Baldini N, Cenacchi A, Bassi A, Giardino R, Fornasari PM, Giunti A. In vivo study on the healing of bone defects treated with bone marrow stromal cells, platelet-rich plasma, and freeze-dried bone allografts, alone and in combination. J Orthop Res. 2006 May;24(5):877-88. [Medline: 16609976] [doi: 10.1002/jor.20112]

70. Kasten P, Vogel J, Geiger F, Niemeyer P, Luginbühl R, Szalay K. The effect of platelet-rich plasma on healing in critical-size long-bone defects. Biomaterials. 2008 Oct;29(29):3983-92. Epub 2008 Jul 9. [Medline: 18614227] [doi: 10.1016/j.biomaterials.2008.06.014]

71. Barone A, Covani U. Maxillary alveolar ridge reconstruction with nonvascularized autogenous block bone: clinical results. J Oral Maxillofac Surg. 2007 Oct;65(10):2039-46. [Medline: 17884536] [doi: 10.1016/i.joms.2007.05.017]

72. Corinaldesi G, Pieri F, Marchetti C, Fini M, Aldini NN, Giardino R. Histologic and histomorphometric evaluation of alveolar ridge augmentation using bone grafts and titanium micromesh in humans. J Periodontol. 2007 Aug;78(8):1477-84. [Medline: 17668966] [doi: 10.1902/jop.2007.070001]

73. Sjöström M, Sennerby L, Nilson H, Lundgren S. Reconstruction of the atrophic edentulous maxilla with free iliac crest grafts and implants: a 3-year report of a prospective clinical study. Clin Implant Dent Relat Res. 2007 Mar;9(1):46-59. [Medline: 17362496] [doi: 10.1111/j.1708-8208.2007.00034.x]

74. Valentini V, Cassoni A, Marianetti TM, Romano F, Terenzi V, Iannetti G. Reconstruction of craniofacial bony defects using autogenous bone grafts: a retrospective study on 233 patients. J Craniofac Surg. 2007 Jul;18(4):953-8. [Medline: 17667694] [doi: 10.1097/scs.0b013e3180690123]

75. Contar CM, Sarot JR, Bordini J Jr, Galvão GH, Nicolau GV, Machado MA. Maxillary ridge augmentation with fresh-frozen bone allografts. J Oral Maxillofac Surg. 2009 Jun;67(6):1280-5. [Medline: 19446217] [doi: 10.1016/j.joms.2008.11.010]

76. Demarosi F, Leghissa GC, Sardella A, Lodi G, Carrassi A. Localised maxillary ridge expansion with simultaneous implant placement: a case series. Br J Oral Maxillofac Surg. 2009 Oct;47(7):535-40. Epub 2009 Jan 15. [Medline: 19150155] [doi: 10.1016/j.bjoms.2008.11.012]

77. Sbordone L, Toti P, Menchini-Fabris GB, Sbordone C, Piombino P, Guidetti F. Volume changes of autogenous bone grafts after alveolar ridge augmentation of atrophic maxillae and mandibles. Int J Oral Maxillofac Surg. 2009 Oct;38(10):105965. Epub 2009 Jul 25. [Medline: 19632815] [doi: 10.1016/j.ijom.2009.06.024]

78. Sbordone L, Toti P, Menchini-Fabris G, Sbordone C, Guidetti F. Implant survival in maxillary and mandibular osseous onlay grafts and native bone: a 3-year clinical and computerized tomographic follow-up. Int J Oral Maxillofac Implants. 2009 Jul-Aug;24(4):695-703. [Medline: 19885411]

79. Acocella A, Bertolai R, Colafranceschi M, Sacco R. Clinical, histological and histomorphometric evaluation of the healing of mandibular ramus bone block grafts for alveolar ridge augmentation before implant placement. J Craniomaxillofac Surg. 2010 Apr;38(3):222-30. Epub 2009 Aug 3. [Medline: 19648020] [doi: 10.1016/j.jcms.2009.07.004]

80. Rachmiel A, Srouji S, Peled M. Alveolar ridge augmentation by distraction osteogenesis. Int J Oral Maxillofac Surg. 2001 Dec;30(6):510-7. [Medline: 11829233] [doi: 10.1054/ijom.2001.0134]

81. Raghoebar GM, Liem RS, Vissink A. Vertical distraction of the severely resorbed edentulous mandible: a clinical, histological and electron microscopic study of 10 treated cases. Clin Oral Implants Res. 2002 Oct;13(5):558-65. [Medline: 12453135] [doi: 10.1034/j.1600-0501.2002.130517.x]

82. Marchetti C, Corinaldesi G, Pieri F, Degidi M, Piattelli A. Alveolar distraction osteogenesis for bone augmentation of severely atrophic ridges in 10 consecutive cases: a histologic and histomorphometric study. J Periodontol. 2007 Feb;78(2):360-6. [Medline: 17274727] [doi: 10.1902/jop.2007.060260]

83. Merli M, Merli M, Triaca A, Esposito M. Segmental distraction osteogenesis of the anterior mandible for improving facial esthetics. Preliminary results. World J Orthod. 2007 Spring;8(1):19-29. [Medline: 17373222]

84. Robiony M, Zorzan E, Polini F, Sembronio S, Toro C, Politi M. Osteogenesis distraction and platelet-rich plasma: combined use in restoration of severe atrophic mandible. Long-term results. Clin Oral Implants Res. 2008 Nov;19(11):1202-10. [Medline: 18983325] [doi: 10.1111/j.1600-0501.2008.01568.x]

85. Krenkel C, Grunert I. The Endo-Distractor for preimplant mandibular regeneration. Rev Stomatol Chir Maxillofac. 2009 Feb;110(1):17-26. Epub 2009 Jan 8. [Medline: 19135219] [doi: 10.1016/j.stomax.2008.09.014]

86. Polimeni G, Wikesjö UM, Susin C, Qahash M, Shanaman RH, Prasad HS, Rohrer MD, Hall J. Alveolar ridge augmentation using implants coated with recombinant human growth/differentiation factor-5: histologic observations. J Clin Periodontol. 2010 Aug 1;37(8):759-68. Epub 2010 May 25. [Medline: 20500538]

87. Urist MR. Bone: formation by autoinduction. Science. 1965 Nov 12;150(698):893-9. [Medline: 5319761] [doi: $10.1126 /$ science. 150.3698 .893 ]

88. Zheng MH, Wood DJ, Wysocki S, Papadimitriou JM, Wang EA. Recombinant human bone morphogenetic protein-2 enhances expression of interleukin-6 and transforming growth factor-beta 1 genes in normal human osteoblast-like cells. J Cell Physiol. 1994 Apr;159(1):76-82. [Medline: $\underline{\text { 8138593] [doi: 10.1002/jcp.1041590111] }}$ 
89. Raida M, Heymann AC, Günther C, Niederwieser D. Role of bone morphogenetic protein 2 in the crosstalk between endothelial progenitor cells and mesenchymal stem cells. Int J Mol Med. 2006 Oct;18(4):735-9. [Medline: 16964430] [FREE Full Text]

90. Boyne PJ. Animal studies of application of rhBMP-2 in maxillofacial reconstruction. Bone. 1996 Jul;19(1 Suppl):83S-92S. [Medline: 8830999$]$

91. Nevins M, Kirker-Head C, Nevins M, Wozney JA, Palmer R, Graham D. Bone formation in the goat maxillary sinus induced by absorbable collagen sponge implants impregnated with recombinant human bone morphogenetic protein-2. Int J Periodontics Restorative Dent. 1996 Feb;16(1):8-19. [Medline: 8631615]

92. Boyne PJ, Marx RE, Nevins M, Triplett G, Lazaro E, Lilly LC, Alder M, Nummikoski P. A feasibility study evaluating rhBMP-2/absorbable collagen sponge for maxillary sinus floor augmentation. Int J Periodontics Restorative Dent. 1997 Feb;17(1):11-25. [Medline: 10332250]

93. Terheyden H, Jepsen S, Möller B, Tucker MM, Rueger DC. Sinus floor augmentation with simultaneous placement of dental implants using a combination of deproteinized bone xenografts and recombinant human osteogenic protein-1. A histometric study in miniature pigs. Clin Oral Implants Res. 1999 Dec;10(6):510-21. [Medline: 10740460] [doi: 10.1034/j.1600-0501.1999.100609.x]

94. Barboza EP, Duarte ME, Geolás L, Sorensen RG, Riedel GE, Wikesjö UM. Ridge augmentation following implantation of recombinant human bone morphogenetic protein-2 in the dog. J Periodontol. 2000 Mar;71(3):488-96. [Medline: 10776939] [doi: 10.1902/jop.2000.71.3.488]

95. Cochran DL, Jones AA, Lilly LC, Fiorellini JP, Howell H. Evaluation of recombinant human bone morphogenetic protein-2 in oral applications including the use of endosseous implants: 3-year results of a pilot study in humans. J Periodontol. 2000 Aug;71(8):1241-57. [Medline: 10972640] [doi: 10.1902/jop.2000.71.8.1241]

96. Ripamonti U, Crooks J, Petit JC, Rueger DC. Periodontal tissue regeneration by combined applications of recombinant human osteogenic protein-1 and bone morphogenetic protein-2. A pilot study in Chacma baboons (Papio ursinus). Eur J Oral Sci. 2001 Aug;109(4):241-8. [Medline: 11531070] [doi: 10.1034/j.1600-0722.2001.00041.x]

97. Wikesjö UM, Qahash M, Thomson RC, Cook AD, Rohrer MD, Wozney JM, Hardwick WR. rhBMP-2 significantly enhances guided bone regeneration. Clin Oral Implants Res. 2004 Apr;15(2):194-204. [Medline: 15008931] [doi: 10.1111/j.1600-0501.2004.00971.x]

98. Boyne PJ, Lilly LC, Marx RE, Moy PK, Nevins M, Spagnoli DB, Triplett RG. De novo bone induction by recombinant human bone morphogenetic protein-2 (rhBMP-2) in maxillary sinus floor augmentation. J Oral Maxillofac Surg. 2005 Dec;63(12):1693-707. [Medline: 16297689] [doi: 10.1016/j.joms.2005.08.018]

99. Fiorellini JP, Howell TH, Cochran D, Malmquist J, Lilly LC, Spagnoli D, Toljanic J, Jones A, Nevins M. Randomized study evaluating recombinant human bone morphogenetic protein-2 for extraction socket augmentation. J Periodontol. 2005 Apr;76(4):605-13. [Medline: 15857102] [doi: 10.1902/jop.2005.76.4.605]

100.Jung RE, Glauser R, Schärer P, Hämmerle CH, Sailer HF, Weber FE. Effect of rhBMP-2 on guided bone regeneration in humans. Clin Oral Implants Res. 2003 Oct;14(5):556-68. [Medline: 12969359] [doi: 10.1034/j.1600-0501.2003.00921.x]

101. Warnke PH, Springer IN, Wiltfang J, Acil Y, Eufinger H, Wehmöller M, Russo PA, Bolte H, Sherry E, Behrens E, Terheyden H. Growth and transplantation of a custom vascularised bone graft in a man. Lancet. 2004 Aug 28-Sep 3;364(9436):766-70. [Medline: 15337402] [doi: 10.1016/S0140-6736(04)16935-3]

102.Medtronic Sofamor Danek, Inc. USA. Summary of Safety and Effectiveness Data, INFUSETM Bone Graft, Memphis, TN, July 2, 2002.

103. Schuckert KH, Jopp S, Müller U. Bone tissue engineering with BMPs - First experiences and results in oral surgery by using rhBMP-2 in humans. Int J Oral Maxillofac Surg. 2005; 34 (Suppl. 1):68. [doi: 10.1016/S0901-5027(05)81141-5]

104. Schuckert KH, Jopp S. Bone Tissue Engineering with BMPs - Are there any advantages of using rhBMP-2 instead of DBM and the transplantation of autogenous bone? Implants 2007(4):14.

105.Dodds RA, York-Ely AM, Zhukauskas R, Arola T, Howell J, Hartill C, Cobb RR, Fox C. Biomechanical and radiographic comparison of demineralized bone matrix, and a coralline hydroxyapatite in a rabbit spinal fusion model. J Biomater Appl. 2010 Sep;25(3):195-215. Epub 2009 Sep 11. [Medline: 19749002] [doi: 10.1177/0885328209345552]

106. Katz JM, Nataraj C, Jaw R, Deigl E, Bursac P. Demineralized bone matrix as an osteoinductive biomaterial and in vitro predictors of its biological potential. J Biomed Mater Res B Appl Biomater. 2009 Apr;89(1):127-34. [Medline: 18780340] [doi: $10.1002 / \mathrm{jbm} \cdot \mathrm{b} .31195$ ]

107. Tsiridis E, Ali Z, Bhalla A, Gamie Z, Heliotis M, Gurav N, Deb S, DiSilvio L. In vitro proliferation and differentiation of human mesenchymal stem cells on hydroxyapatite versus human demineralised bone matrix with and without osteogenic protein-1. Expert Opin Biol Ther. 2009 Jan;9(1):9-19. [Medline: 19063689] [doi: 10.1517/14712590802622473]

108. Drosos GI, Kazakos KI, Kouzoumpasis P, Verettas DA. Safety and efficacy of commercially available demineralised bone matrix preparations: a critical review of clinical studies. Injury. 2007 Sep;38 Suppl 4:S13-21. Review. [Medline: 18224733] [doi: 10.1016/S0020-1383(08)70005-6]

109. Kinney RC, Ziran BH, Hirshorn K, Schlatterer D, Ganey T. Demineralized bone matrix for fracture healing: fact or fiction? J Orthop Trauma. 2010 Mar;24 Suppl 1:S52-5. [Medline: 20182237] [doi: 10.1097/BOT.0b013e3181d07ffa] 
110. Bormann N, Pruss A, Schmidmaier G, Wildemann B. In vitro testing of the osteoinductive potential of different bony allograft preparations. Arch Orthop Trauma Surg. 2009 Jun 16. [Epub ahead of print] [Medline: 19529951]

111. Wang JC, Alanay A, Mark D, Kanim LE, Campbell PA, Dawson EG, Lieberman JR. A comparison of commercially available demineralized bone matrix for spinal fusion. Eur Spine J. 2007 Aug;16(8):1233-40. Epub 2007 Jan 5. [Medline: 17205237] [doi: 10.1007/s00586-006-0282-x] [FREE Full Text]

112. Hoffer MJ, Griffon DJ, Schaeffer DJ, Johnson AL, Thomas MW. Clinical applications of demineralized bone matrix: a retrospective and case-matched study of seventy-five dogs. Vet Surg. 2008 Oct;37(7):639-47. [Medline: 19134086] [doi: 10.1111/j.1532-950X.2008.00430.x]

113. Schizas C, Triantafyllopoulos D, Kosmopoulos V, Tzinieris N, Stafylas K. Posterolateral lumbar spine fusion using a novel demineralized bone matrix: a controlled case pilot study. Arch Orthop Trauma Surg. 2008 Jun;128(6):621-5. Epub 2007 Nov 3. [Medline: 17978826] [doi: 10.1007/s00402-007-0495-4]

114. Park HW, Lee JK, Moon SJ, Seo SK, Lee JH, Kim SH. The efficacy of the synthetic interbody cage and Grafton for anterior cervical fusion. Spine (Phila Pa 1976). 2009 Aug 1;34(17):E591-5. [Medline: 19644317]

115. Liu G, Sun J, Li Y, Zhou H, Cui L, Liu W, Cao Y. Evaluation of partially demineralized osteoporotic cancellous bone matrix combined with human bone marrow stromal cells for tissue engineering: an in vitro and in vivo study. Calcif Tissue Int. 2008 Sep;83(3):176-85. Epub 2008 Aug 15. [Medline: 18704250] [doi: 10.1007/s00223-008-9159-9]

116. Pieske O, Wittmann A, Zaspel J, Löffler T, Rubenbauer B, Trentzsch H, Piltz S. Autologous bone graft versus demineralized bone matrix in internal fixation of ununited long bones. J Trauma Manag Outcomes. 2009 Dec 15;3:11. [Medline: 20003511] [doi: 10.1186/1752-2897-3-11] [FREE Full Text]

117. Butcher A, Milner R, Ellis K, Watson JT, Horner A. Interaction of platelet-rich concentrate with bone graft materials: an in vitro study. J Orthop Trauma. 2009 Mar;23(3):195-200; discussion 201-2. [Medline: 19516093] [doi: 10.1097/BOT.0b013e31819b35db]

118.Li NY, Yuan RT, Chen T, Chen LQ, Jin XM. Effect of platelet-rich plasma and latissimus dorsi muscle flap on osteogenesis and vascularization of tissue-engineered bone in dogs. J Oral Maxillofac Surg. 2009 Sep;67(9):1850-8. [Medline: 19686921] [doi: 10.1016/i.joms.2009.04.029]

119. Kuvat SV, Cizmeci O, Biçer A, Marşan G, Hocaoğlu E, Bilgiç B, Emekli U. Improving bony stability in maxillofacial surgery: use of osteogenetic materials in patients with profound ( $>$ or $=5 \mathrm{~mm}$ ) maxillary advancement, a clinical study. J Plast Reconstr Aesthet Surg. 2009 May;62(5):639-45. Epub 2008 Mar 28. [Medline: 18375195] [doi: 10.1016/j.bjps.2007.09.043]

120.Sohn DS, Bae MS, Choi BJ, An KM, Shin HI. Efficacy of demineralized bone matrix paste for maxillary sinus augmentation: a histologic and clinical study in humans. Oral Surg Oral Med Oral Pathol Oral Radiol Endod. 2009 Nov;108(5):e30-5. [Medline: 19836711] [doi: 10.1016/j.tripleo.2009.06.042]

121.Aichelmann-Reidy ME, Reynolds MA. Predictability of clinical outcomes following regenerative therapy in intrabony defects. J Periodontol. 2008 Mar;79(3):387-93. Review. [Medline: 18315419] [doi: 10.1902/jop.2008.060521]

122. Kaya Y, Yalim M, Bahçecitapar M, Baloş K. Comparison of applying particulate demineralized bone matrix (DBM), putty DBM and open flap debridement in periodontal horizontal bone defects. A 12-month longitudinal, multi-center, tripleblind, split-mouth, randomized, controlled clinical study. Part 1 - clinical and radiographic evaluation. J Oral Rehabil. 2009 Jul;36(7):524-34. Epub 2009 May 18. [Medline: 19453850] [doi: 10.1111/j.1365-2842.2009.01958.x]

123.Lin H, Zhao Y, Sun W, Chen B, Zhang J, Zhao W, Xiao Z, Dai J. The effect of crosslinking heparin to demineralized bone matrix on mechanical strength and specific binding to human bone morphogenetic protein-2. Biomaterials. 2008 Mar;29(9):1189-97. [Medline: 18083224] [doi: 10.1016/j.biomaterials.2007.11.032]

124.Zhao Y, Zhang J, Wang X, Chen B, Xiao Z, Shi C, Wei Z, Hou X, Wang Q, Dai J. The osteogenic effect of bone morphogenetic protein-2 on the collagen scaffold conjugated with antibodies. J Control Release. 2010 Jan 4;141(1):30-7. Epub 2009 Jul 4. [Medline: 19580831] [doi: 10.1016/j.jconrel.2009.06.032]

125. Tsiridis E, Ali Z, Bhalla A, Heliotis M, Gurav N, Deb S, DiSilvio L. In vitro and in vivo optimization of impaction allografting by demineralization and addition of rh-OP-1. J Orthop Res. 2007 Nov;25(11):1425-37. [Medline: 17557338 ] [doi: 10.1002/jor.20387]

126. Clokie CM, Sándor GK. Reconstruction of 10 major mandibular defects using bioimplants containing BMP-7. J Can Dent Assoc. 2008 Feb;74(1):67-72. [Medline: 18298888]

127. Hutmacher DW. Scaffolds in tissue engineering bone and cartilage. Biomaterials. 2000 Dec;21(24):2529-43. [Medline: 11071603] [doi: 10.1016/S0142-9612(00)00121-6]

128.Zein I, Hutmacher DW, Tan KC, Teoh SH. Fused deposition modeling of novel scaffold architectures for tissue engineering applications. Biomaterials. 2002 Feb;23(4):1169-85. [Medline: 11791921] [doi: 10.1016/S0142-9612(01)00232-0]

129. Rai B, Teoh SH, Ho KH. An in vitro evaluation of PCL-TCP composites as delivery systems for platelet-rich plasma. J Control Release. 2005 Oct 3;107(2):330-42. [Medline: 16085332] [doi: 10.1016/j.jconrel.2005.07.002]

130. Rai B, Teoh SH, Ho KH, Hutmacher DW, Cao T, Chen F, Yacob K. The effect of rhBMP-2 on canine osteoblasts seeded onto 3D bioactive polycaprolactone scaffolds. Biomaterials. 2004 Nov;25(24):5499-506. [Medline: 15142731] [doi: 10.1016/j.biomaterials.2004.01.007]

131. Rai B, Teoh SH, Hutmacher DW, Cao T, Ho KH. Novel PCL-based honeycomb scaffolds as drug delivery systems for rhBMP-2. Biomaterials. 2005 Jun;26(17):3739-48. [Medline: 15621264] [doi: 10.1016/j.biomaterials.2004.09.052] 
132.Tsiridis E, Bhalla A, Ali Z, Gurav N, Heliotis M, Deb S, DiSilvio L. Enhancing the osteoinductive properties of hydroxyapatite by the addition of human mesenchymal stem cells, and recombinant human osteogenic protein-1 (BMP-7) in vitro. Injury. 2006 Sep;37 Suppl 3:S25-32. Erratum in: Injury. 2007 Oct;38(10):1224. [Medline: 16963359] [doi: 10.1016/j.injury.2006.08.021]

133. Kretlow JD, Young S, Klouda L, Wong M, Mikos AG. Injectable biomaterials for regenerating complex craniofacial tissues. Adv Mater. 2009 Sep 4;21(32-33):3368-93. [Medline: 19750143] [doi: 10.1002/adma.200802009] [FREE Full Text]

134. Ripamonti U, Heliotis M, Ferretti C. Bone morphogenetic proteins and the induction of bone formation: from laboratory to patients. Oral Maxillofac Surg Clin North Am. 2007 Nov;19(4):575-89, vii. Review. [Medline: 18088907] [doi: 10.1016/i.coms.2007.07.006]

135. Heliotis M, Ripamonti U, Ferretti C, Kerawala C, Mantalaris A, Tsiridis E. The basic science of bone induction. Br J Oral Maxillofac Surg. 2009 Oct;47(7):511-4. Epub 2009 Mar 10. Review. [Medline: 19278759] [doi: 10.1016/j.bjoms.2009.01.013]

136. Wikesjö UM, Huang YH, Polimeni G, Qahash M. Bone morphogenetic proteins: a realistic alternative to bone grafting for alveolar reconstruction. Oral Maxillofac Surg Clin North Am. 2007 Nov;19(4):535-51, vi-vii. Review. [Medline: 18088904] [doi: 10.1016/j.coms.2007.07.004]

137. Wikesjö UM, Qahash M, Polimeni G, Susin C, Shanaman RH, Rohrer MD, Wozney JM, Hall J. Alveolar ridge augmentation using implants coated with recombinant human bone morphogenetic protein-2: histologic observations. J Clin Periodontol. 2008 Nov;35(11):1001-10. [Medline: 18976397] [doi: 10.1111/j.1600-051X.2008.01321.x]

138. Wikesjö UM, Xiropaidis AV, Qahash M, Lim WH, Sorensen RG, Rohrer MD, Wozney JM, Hall J. Bone formation at recombinant human bone morphogenetic protein-2-coated titanium implants in the posterior mandible (Type II bone) in dogs. J Clin Periodontol. 2008 Nov;35(11):985-91. [Medline: 18976395] [doi: 10.1111/j.1600-051X.2008.01318.x]

139. Wikesjö UM, Qahash M, Huang YH, Xiropaidis A, Polimeni G, Susin C. Bone morphogenetic proteins for periodontal and alveolar indications; biological observations - clinical implications. Orthod Craniofac Res. 2009 Aug;12(3):263-70. Review. [Medline: 19627529] [doi: 10.1111/j.1601-6343.2009.01461.x]

140.Leknes KN, Yang J, Qahash M, Polimeni G, Susin C, Wikesjö UM. Alveolar ridge augmentation using implants coated with recombinant human bone morphogenetic protein-2: radiographic observations. Clin Oral Implants Res. 2008 Oct;19(10):1027-33. [Medline: 18828819] [doi: 10.1111/j.1600-0501.2008.01567.x]

141. Wikesjö UM, Qahash M, Polimeni G, Susin C, Shanaman RH, Rohrer MD, Wozney JM, Hall J. Alveolar ridge augmentation using implants coated with recombinant human bone morphogenetic protein-2: histologic observations. J Clin Periodontol. 2008 Nov;35(11):1001-10. [Medline: 18976397] [doi: 10.1111/j.1600-051X.2008.01321.x]

\section{To cite this article:}

Schuckert KH, Jopp S, Osadnik M. The Use of Platelet Rich Plasma, Bone Morphogenetic Protein-2 and Different Scaffolds in Oral and Maxillofacial Surgery - Literature Review in Comparison with Own Clinical Experience.

J Oral Maxillofac Res 2011;2(1):e2

URL: http://www.ejomr.org/JOMR/archives/2011/1/e2/v2n1e2ht.pdf

doi: $10.5037 /$ jomr.2011.2102

Copyright (C) Schuckert KH, Jopp S, Osadnik M. Accepted for publication in the JOURNAL OF ORAL \& MAXILLOFACIAL RESEARCH (http://www.ejomr.org), 18 January 2011.

This is an open-access article, first published in the JOURNAL OF ORAL \& MAXILLOFACIAL RESEARCH, distributed under the terms of the Creative Commons Attribution-Noncommercial-No Derivative Works 3.0 Unported License, which permits unrestricted non-commercial use, distribution, and reproduction in any medium, provided the original work and is properly cited. The copyright, license information and link to the original publication on (http://www.ejomr.org) must be included. 